\title{
Analysis of Student's Conceptual Understanding on Visualization Phase in Learning Geometry by Using Spinning Wheel Media
}

\author{
Riny Sulfiyah, Baiduri, Agung Deddiliawan Ismail \\ Study Program of Mathematics Education, Faculty of Teacher Training and Education \\ University of Muhammadiyah Malang \\ rinysulfiyahriny@gmail.com
}

\begin{abstract}
This research aimed to describe the result of using the spinning wheel with steps based on Van Hiele theory, and to know student's conceptual understanding in visualization phase through spinning wheel media and to describe the effectiveness of spinning wheel in improving student level of thinking from visualization phase to analysis phase. This research was descriptive research on experimental teaching which the research subject was seventh grade students at junior high school 4 Pamekasan consisted of 26 visualization phase students. The data collection techniques used in this research were observation, test, and interview. The resulting research showed that the learning process by using Van Hiele learning theory and spinning wheel media could attract student's interest in the learning process, so students had the good conceptual understanding. Besides, the result showed the student's understanding level at SMP 4 Pamekasan, it divided into two categories which were very good; and good. In the very good category, the average score was $89,5 \%$. Then, a student's conceptual understanding in the good category has $70,99 \%$ as the average score. It also stated that the spinning wheel that had been used was effective. It stated as effective because the spinning wheel media could improve from student's visualization thinking to student's analytical thinking level. Keywords: Conceptual Understanding, Van Hiele learning theory, spinning wheel media
\end{abstract}

\section{INTRODUCTION}

Geometry is a part of mathematics that is related to the relationship between points, lines, angles, plane geometry and solid geometry (Salim K \&Tlawa, 2015). Geometry learning can help develop logical thinking skills, deductive thinking, analytical thinking and problem solving (Armah, Cofie, \&Okpoti, 2018). The geometry ability that students need to possess is to be able to describe geometric shapes, be able to analyze the character and nature of geometric shapes, and be able to make comparisons of each geometric shapes (Al-ebous, 2016). Geometry learning will be understood easily by students if they understand the concept of geometry.

Understanding the concept is the main requirement for the further learning process, without understanding the concept it will be difficult to make students understand the next material. Based on that thing, the understanding of geometry concept is very important in learning mathematics to understand another field in mathematics (Jelatu, Sariyasa \& Ardana, 2018). Understanding the geometry concept can help students think logically and deductively about some mathematical objects and their relationships (Alqahtani \& Powell, 2016). 
Based on observation and interview on November 10th, 2017 at SMP 4 Pamekasan, students were still got difficulty in understanding the concepts of geometry. The cause of student's difficulties in understanding geometry concepts was because of the geometry learning process still used conventional methods such as the teacher only use blackboard to draw. When students were asked to solve a question or asked to mention the elements of geometric shapes, students were still confused. Some teachers used media in learning activities, but they have not succeeded yet. It has not succeeded mean that students have not fully absorbed the material conveyed by the teacher using the existing media.

According to the results of the interview with the teacher, this happened because the media used were not suitable with the level of student's thinking. Each a student has different level of thinking. Thus, the media, models and methods that used must suitable with the level of student's understanding. Safrina (2014) said that difficulties in learning geometry were still experienced by students. One of the reasons is the learning strategy used is not appropriate with the level of thinking of students, so that the proper strategy is needed. The strategy is designed based on the level of student's thinking in learning geometry.

Van Hiele's theory is a theory that learning about the level of student's thinking. The level of thinking in this theory is called a phase or stage. There are five phases of thinking, starting from the simplest phase to the highest phase. Van Hiele's theory consists of five thinking phases namely visualization phase, analysis phase, sequencing phase, deduction phase, and accuracy phase (Alex \&Mammen, 2015). Yadil (2009) said that Van Hiele's learning model was able to improve student's understanding of concepts, because on his theory they studied stages of thinking, so we can understand in advance what student's need, thus the material can be conveyed to students according to the stages of their thinking. The statement was also supported by (Alex \&Mammen, 2015) who said that Van Hiele's Theory could provide an understanding of geometry and could develop an understanding of geometry concepts. The level of thinking development according to Van Hiele's theory is visualization or recognition phase, at this level new students know what geometry is. For example, at this stage new students recognize rectangles as rectangular objects such as doors, books, etc (Ketut, 2014).

Susanti (2011) stated that mathematics learning in the educational world is still very far from what is expected, there are still many students who do not understand what the teacher wants to say. For example on plane sides, students recognize that a square is a shape that has four equal sides. Yadil (2009) research also stated that students were generally in the first stage, namely visualization stage or phase, this could be seen from the results of tests performed on Junior High School students in Palu, in his research students only recognize the name of a plane, students cannot mention the properties that are in a plane. The researcher could finally conclude that media was the right tool to solve the problems above, because media plays an important role in the learning process, by using media students will be easier to understand the material presented. Learning by using media could also make students more enthusiastic about learning, so the material delivered can be accepted and understood easily.

Karim (2011) analyzed the understanding of student's concept by using guided discovery, the data analysis in his study concluded that mathematics learning with guided discovery methods was better than conventional learning in improving student understanding of concepts and critical thinking skills in high, medium, and low level and 
most students showed positive attitudes towards learning mathematics through guided discovery methods.

According to Susilana \& Riyana (2009) media could attract student's interest in the learning process, students experienced direct interaction between students and learning resources. It allowed students to learn independently based on their visual, auditory and kinesthetic talents and abilities, and provided stimuli to students. Yeni (2011) said that manipulative objects can improve student's understanding of concepts, because with manipulative objects students can receive stimulation of learning material easily, especially in geometry.

Based on the explanation above, the researcher designed a learning media in the form of spinning wheel that used as a tool for the student in learning and helped students understand geometry material, so students were easier to understand the basic concepts in geometry material. The existence of the spinning wheel media aimed to make students who were initially in the visualization phase could increase to analysis phase by looking at the level of concept understanding. Spinning wheel media could be stated as effective media in learning if the goal was achieved perfectly.

\section{RESEARCH METHOD}

This research used a descriptive experimental teaching type. Experimental teaching research was a type of research that was used to see the development of research subject through the learning process provided by the teacher. The approach used in this study was a qualitative and quantitative approach. The qualitative approach was used to describe the implementation of learning through media by looking at the level of student's thinking used Van Hiele's theory and to describe the student's understanding of concepts in learning geometry. The subjects in this study were seventh grade (VII) students at junior high school 4 Pamekasan, in the odd semester of academic year 2018/2019, which were at visualization thinking phase. he data collection on student's conceptual understanding was done by observing students activities in learning and student's answers on sheets of the test. Data analysis technique included the analysis data of observations. The researcher tried to find data about a student's conceptual understanding of the learning by using the spinning wheel media that students learned. When learning took place, observations were held regarding conceptual understanding. The test was also used to see the level of student's conceptual understanding that could be seen from the way students answered the questions test which was given by researchers after operating the spinning wheel media in the learning process.

\section{RESULT AND DISCUSSION}

The steps used in this learning are using the wheel turning media and the stages of learning Van Hiele's theory in the visualization phase students. This learning process is used to see the ability to understand the concept of students in the visualization phase, here are the student learning outcomes at meeting 1 and meeting 2:

\section{1. $1^{\text {st }}$ Meeting}

\section{a. Information Stage}

Students listened to the teacher's explanation of how to use the spinning wheel media. The teacher informed or introduced students to plane, so students try to think about the shape of a plane and anything that has plane shape. Students tried to find information about the square. In this stage students began to know the type of quadrilateral from the 
student's book. This could be seen from the results of the dialogue between the teacher and students in the classroom, the following were student's dialogue in seeking information:

\begin{tabular}{|c|c|}
\hline Teacher & $\begin{array}{l}\text { :"Today we are going to learn about plane geometry, do you know the kinds of a } \\
\text { plane?" }\end{array}$ \\
\hline Students & : (Simultaneously students answered) "No, ma'am." \\
\hline Teacher & $\begin{array}{l}\text { "The example of a plane in daily life is the floor you step on, look at the shape of } \\
\text { each unit, it is called a square." }\end{array}$ \\
\hline Student & :"Then the asbestos is also a square ma'am?" \\
\hline Teacher & $\begin{array}{l}: \text { "Yeah, it's also square, but asbestos is a rectangle. Does anyone know what is the } \\
\text { difference between square and rectangle?" }\end{array}$ \\
\hline Student & : "Square has 4 equal sides, while rectangles have two equal sides." \\
\hline
\end{tabular}

\section{b. Guide Orientation Stage}

Students began to apply the spinning wheel media and began to understand the plane to draw the media. In this case, students found out the characteristic of each plane (triangles and squares). Students were required to be active in observing the spinning wheel media. In this stage, students already understood the quadrilateral. Students had been able to classify the type of quadrilateral by using media. This could be seen from the class activities. They were very active in their group. Students were able to explain the quadrilateral concept. It could be seen from the results of the question and answer activity that the teacher carried out in the middle of the observation process, such as the following conversation:

\begin{tabular}{ll}
\hline Teacher & $:$ "Please mention the type of shape you know?" \\
Student & $:$ "Quadrilateral." \\
Teacher & $:$ "What are the types of the quadrilateral?" \\
Student & : Square, rectangle, trapezoid, rhombus, kite, parallelogram. \\
\hline
\end{tabular}

\section{c. Explication Stage}

In this stage, students wrote their observations on the spinning wheel media. Students had know about quadrilateral, including the definition of shape and the basic characteristics of shape. At this stage students have been able to reach the learning indicator with the rotating wheel media. Students are able to write down the results of the rotating wheel media. Students were able to clarify objects based on certain characteristics with the concept. It was known by student's ability in understanding the sides, angles and diagonals in plane figure sequentially. Students were able to give examples and not examples of the geometry concept. For example, students were able to give an example of geometry including quadrilateral. It was seen based on the results of group discussions observed by the researcher during the learning process through the spinning wheel media. The following table was the result of spinning wheel media regarding quadrilateral sub-material: 


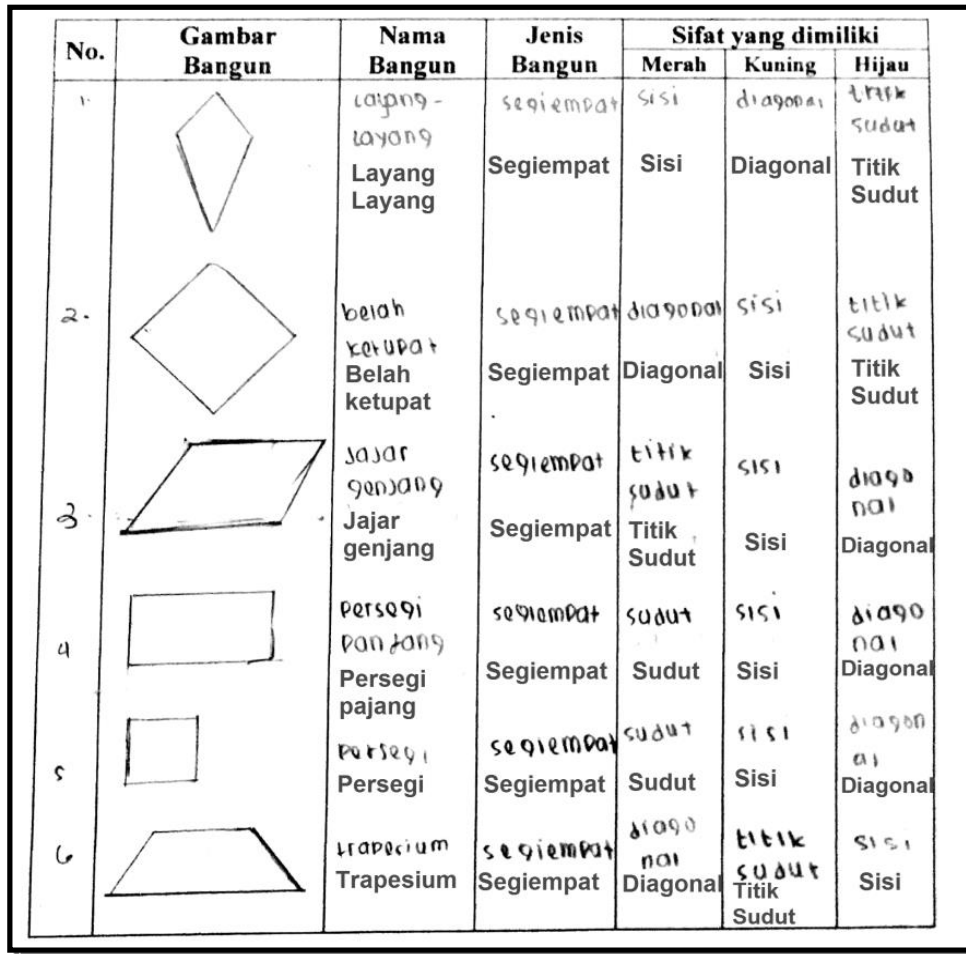

Note: The typing word was the affirmation writing from the researcher

The hand writing was the original writing of the subject

The following was the student's conceptual understanding which students were able to give examples and not examples of a concept as an indicator:

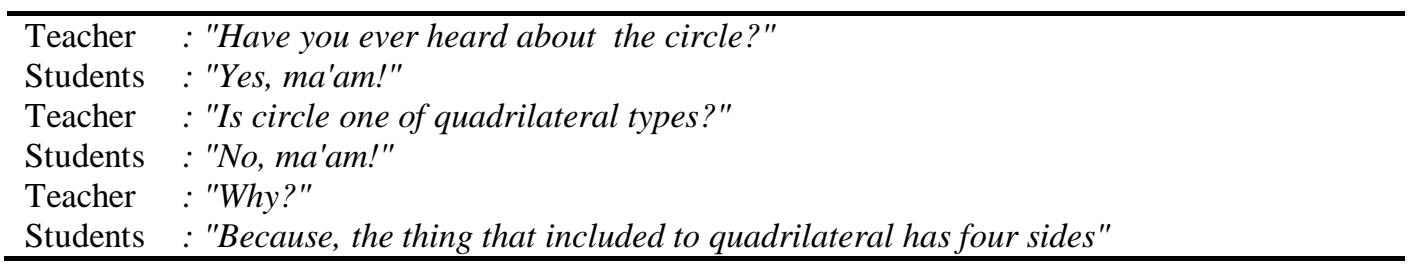

\section{d. Free Orientation Stage}

In this stage, students did exercise in the second sheet of the observation sheet. It can be seen from the student's discussion and the student's answer that they have been understood the concept of the quadrilateral. At this stage, students had been able to develop the necessary requirement and sufficient requirements of a concept on their own way. Students were able to complete a concept correctly based on certain steps. 


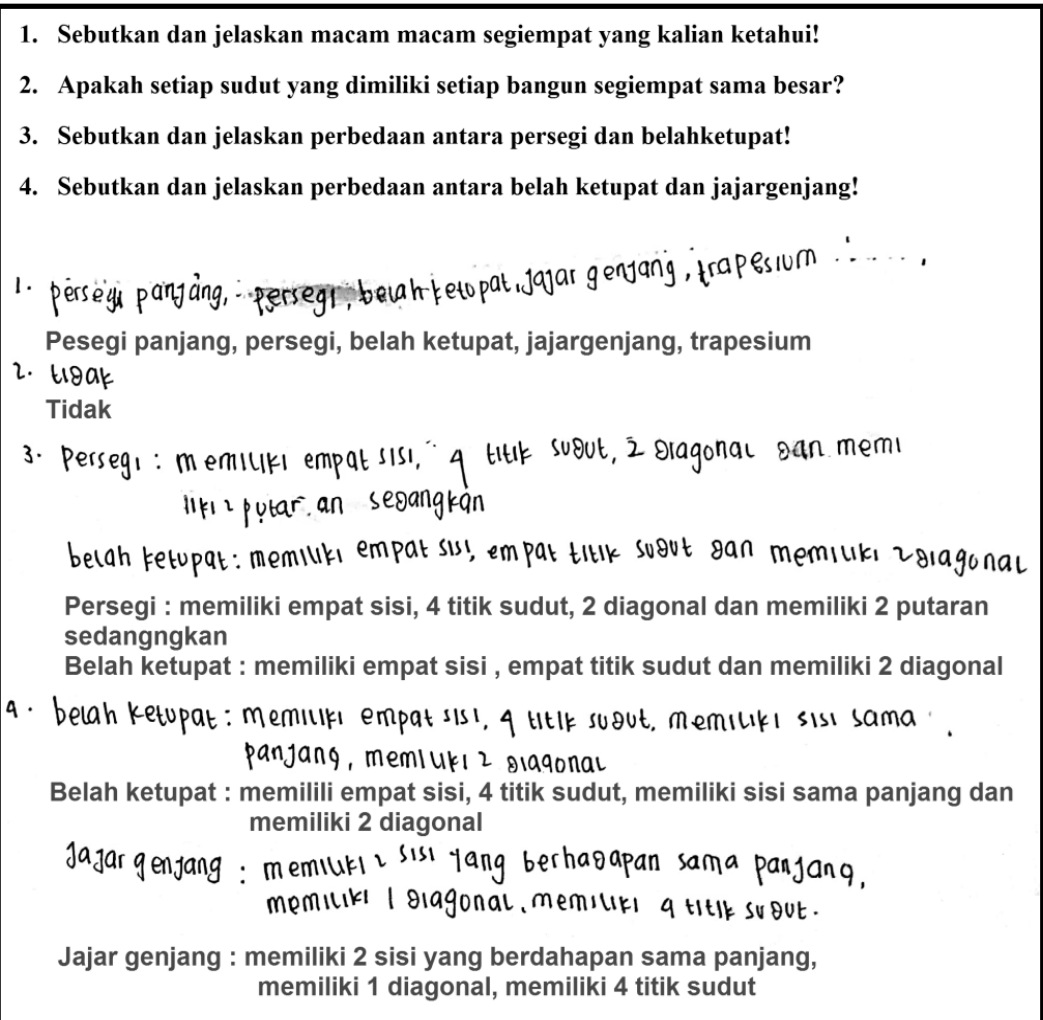

Note: The typing word was the affirmation writing from the researcher

The hand writing was the original writing of the subject

\section{e. Integration Stage}

The last stage is the integration stage, at this stage students were able to choose a concept and explain it directly. They also could conclude the results of learning about the plane (quadrilateral). The very last stage was students gave conclusions about the characteristics of the plane that they had learned by using the spinning wheel media which was combined with the Van Hiele learning model. The role of the teacher here was to straighten out the conclusions that the students stated. It was because the teacher was a facilitator. The table following were the results of the way students conclude learning outcomes of the $1^{\text {st }}$ meeting:

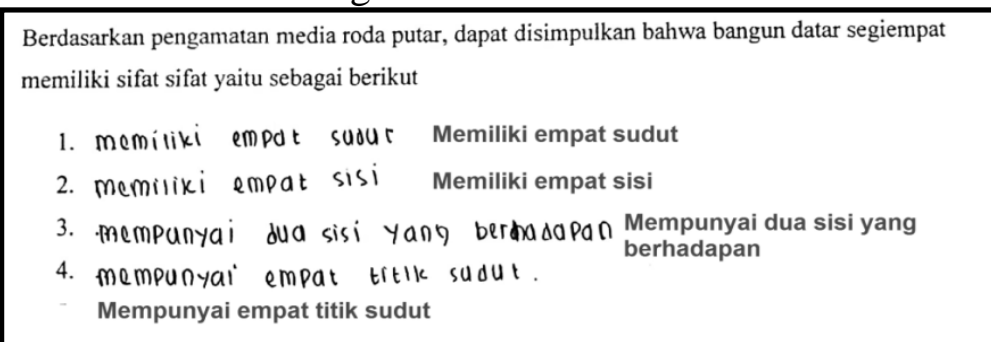

Note: The typing word was the affirmation writing from the researcher

The hand writing was the original writing of the subject

The results of observations at the $1^{\text {st }}$ meeting were assessed by 2 observers as follows: 
Table 6 Results of $1^{\text {st }}$ Meeting Observation Analysis

\begin{tabular}{|c|c|c|c|c|}
\hline \multirow{3}{*}{ Assessed Aspects } & \multirow{2}{*}{\multicolumn{2}{|c|}{$\frac{\text { Percentage }(\%)}{\text { Observer }}$}} & \multirow{3}{*}{ Average } & \multirow{3}{*}{ Category } \\
\hline & & & & \\
\hline & (1) & (2) & & \\
\hline $\begin{array}{l}\text { Information Stage } \\
\text { - Finding information }\end{array}$ & $100 \%$ & $100 \%$ & $100 \%$ & Very good \\
\hline $\begin{array}{l}\text { Guide orientation Stage } \\
\text { - Re-stating a concept }\end{array}$ & $85 \%$ & $80 \%$ & $82,5 \%$ & Very good \\
\hline $\begin{array}{l}\text { Explication Stage } \\
\text { - Clarifying an object based on a certain characteristic } \\
\text { - Giving examples and not examples of concepts }\end{array}$ & $87,5 \%$ & $75 \%$ & $81,3 \%$ & Very good \\
\hline $\begin{array}{l}\text { Free Orientation Stage } \\
\text { - Presenting concepts in the form of representation } \\
\text { - Developing sufficient requirements and necessary } \\
\text { - } \text { requirements. }\end{array}$ & $81,25 \%$ & $81 \%$ & $81,1 \%$ & Very good \\
\hline $\begin{array}{l}\text { Integration Stage } \\
\text { - Students are able to apply concepts or algorithms to solve } \\
\text { mathematical concepts }\end{array}$ & $91,6 \%$ & $85 \%$ & $88,3 \%$ & Very good \\
\hline
\end{tabular}

\section{2. $2^{\text {nd }}$ Meeting}

Related to the results of the $1^{\text {st }}$ meeting evaluation that the researcher used, the second meeting applied the following learning stages:

\section{a. Information Stage}

At the second meeting the students observed the rotating wheel media again but in this meeting the sub-material was a triangle. The students did not need to be redirected, because students already understand what they should do in the information stage. In the information stage in this second meeting, students had understood the type of triangle. It showed when the researcher conducted the dialogue in the classroom, as follows:

$\begin{array}{ll}\text { Teacher } & \begin{array}{l}\text { "As we learned yesterday, today we will learn about plane geometry again, } \\ \text { yesterday we learned about quadrilateral, but today we will learn other types of } \\ \text { plane geometry. Have you ever heard about the triangle?" }\end{array} \\ \text { Students } & \begin{array}{l}\text { : (Simultaneously students answered) "Yes, ma'am." } \\ \text { Teacher } \\ \text { Student }\end{array} \\ & \begin{array}{l}\text { triangle and quadrilateral? } \\ \text { : "The triangle has three sides, while a quadrilateral has four sides." }\end{array}\end{array}$

\section{b. Guide Orientation Stage}

Students started to apply the spinning wheel media again and started to understand the geometry that existed in the media, in this case students could find out the characteristic of each plane geometry (triangle). Students were required to be active in observing the spinning wheel. Students already understood about quadrilateral. Students could classify the type of quadrilateral used media. This could be seen from class activities. They were very active in their group. At this stage, students were able to explain the concept of the triangle. It showed in the results of the question and answer activity that the teacher did in the middle of the observation process, such as the following conversation:

\footnotetext{
Teacher : "Please mention the type of geometry that you know."

Student : : Quadrilateral and triangle."

Teacher : "What is the example of the triangle?"

Student : "Equilateral triangle, isosceles, and scalene."
} 


\section{c. Explication Stage}

Students in this step started writing their observations on the spinning wheel. At this stage, students had already known about the triangle, including the definition of the plane and the basic characteristics of the plane. In this stage students had been able to achieve the learning indicator by using the spinning wheel. Students were able to write down the results of observations of the spinning wheel. Besides, Students were able to clarify objects based on certain characteristics with the concept. It was known by student's ability in understanding the sides, angles and diagonals in plane figure sequentially. Students were able to give examples and not examples of the geometry concept. For example, students are able to give an example of the triangle. It was seen based on the results of group discussions observed by the researcher during the learning process through the spinning wheel media. The following table was the result of spinning wheel media regarding quadrilateral sub-material:

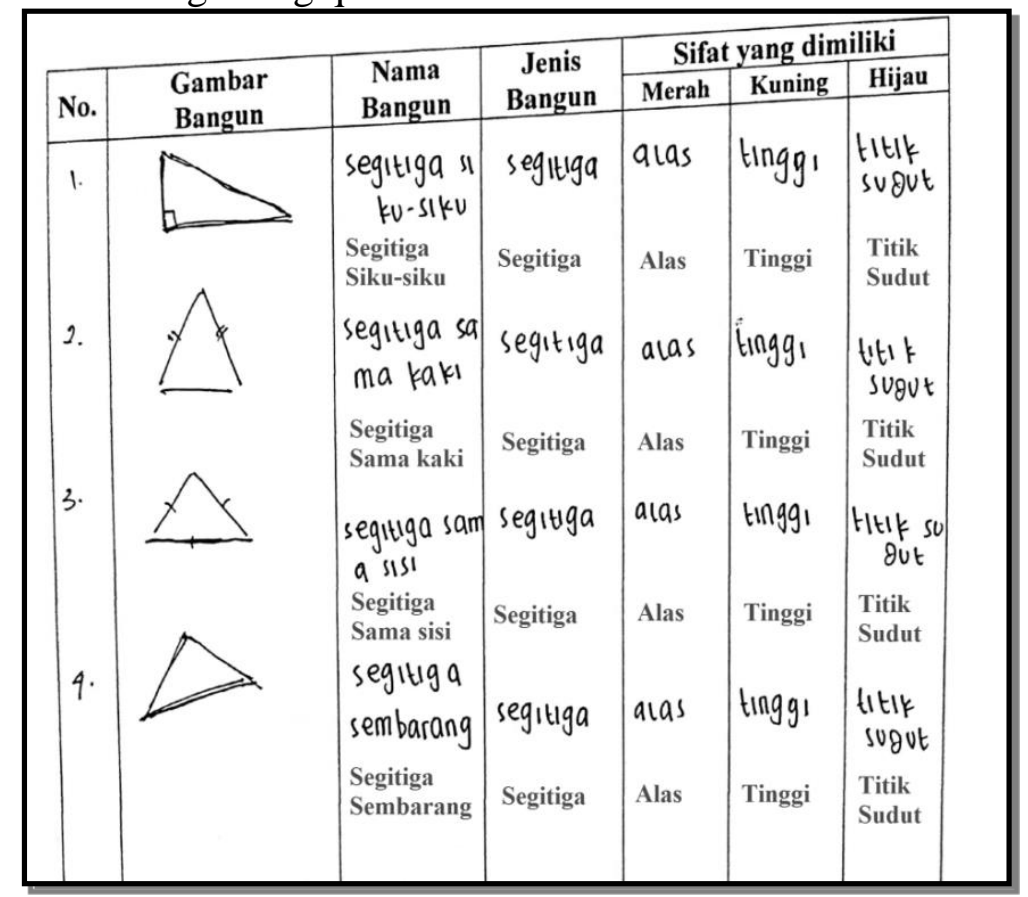

Note: The typing word was the affirmation writing from the researcher

The hand writing was the original writing of the subject

The following the was student's conceptual understanding which students were able to give examples and not examples of a concept as the indicator:

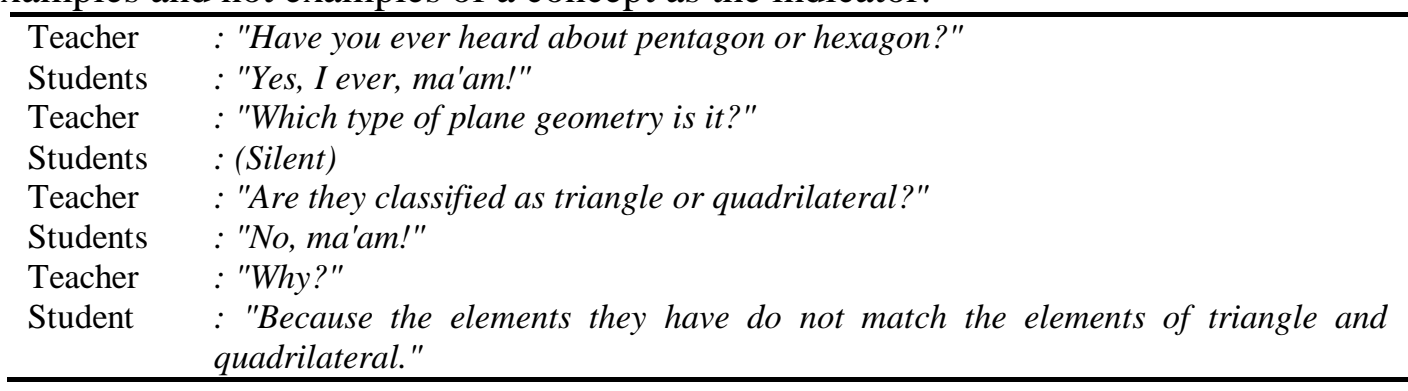

\section{d. Free Orientation Stage}

In this stage students answered questioned practice in the second sheet of the observation sheet. It can be seen from the student's discussion and student's answer that they have 
been understood the concept of the triangle. At this stage, students had been able to develop the necessary requirement and sufficient requirements of a concept on their own way. Students were able to complete a concept correctly based on certain steps. The image following was the results of the student's work:

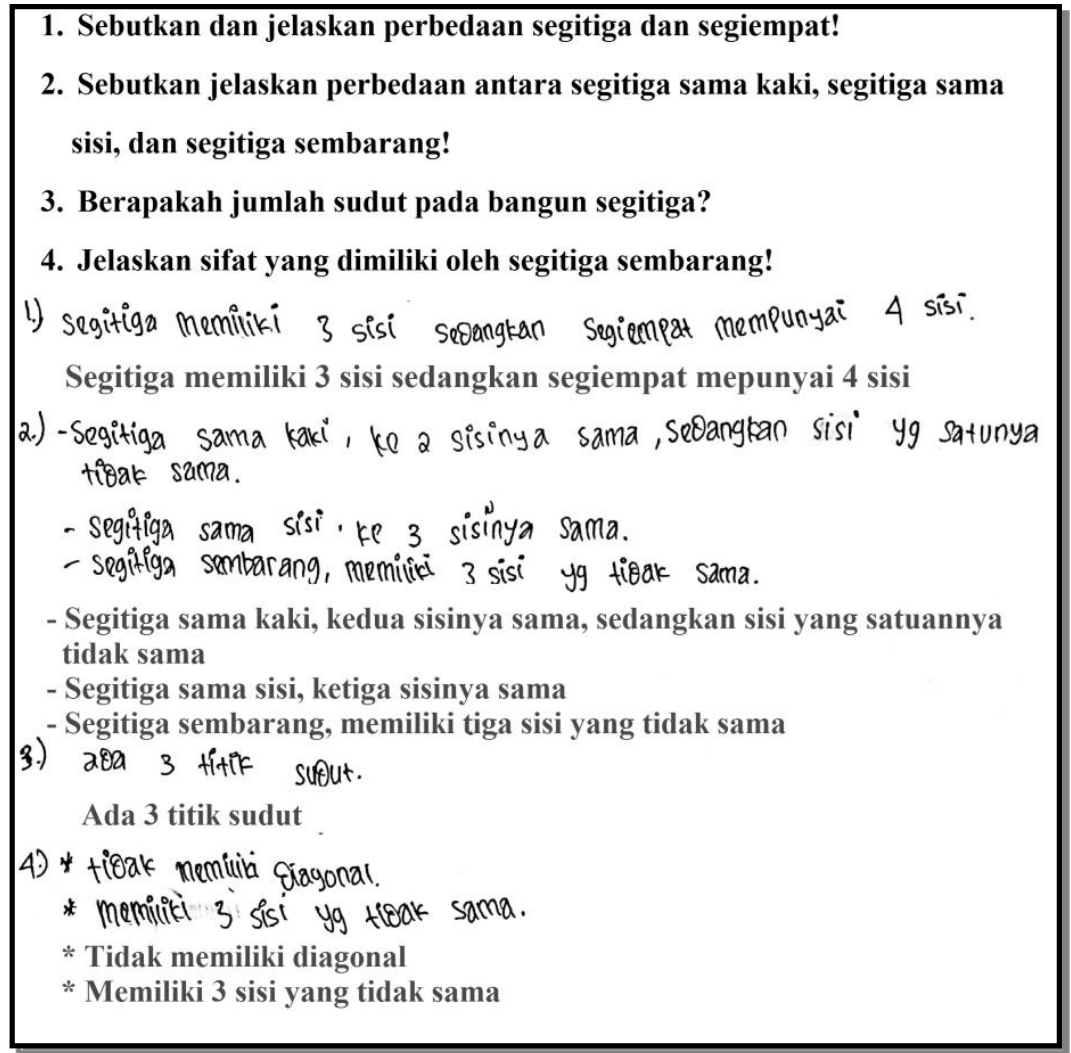

Note: The typing word was the affirmation writing from the researcher

The hand writing was the original writing of the subject

\section{Integration Stage}

The last stage is the integration stage, at this stage students were able to choose a concept and explain it directly. They also could conclude the results of the learning about the plane (triangle). The very last stage was students gave conclusions about the characteristics of plane that they had learned by using the spinning wheel media which was combined with the Van Hiele's learning model. The role of the teacher here was to straighten out the conclusions that the students stated. It was because the teacher was a facilitator. The table following were the results of the way students conclude learning outcomes of the $2^{\text {nd }}$ meeting:

$$
\begin{aligned}
& \text { Berdasarkan pengamatan media roda putar, dapat disimpulkan bahwa bangun datar segitiga } \\
& \text { memiliki sifat sifat yaitu sebagai berikut } \\
& \text { 1. Memılı| tıga sIsı Memiliki tiga sisi } \\
& \text { 2. mempunyaı tıga titık susut Mempunyai tiga titik sudut } \\
& \text { 3. tioak memitiki oragona Tidak memiliki diagonal } \\
& 4 .
\end{aligned}
$$

Note: The typing word was the affirmation writing from the researcher

The hand writing was the original writing of the subject 
The results of the study were analyzed based on the data obtained through observations, tests and interviews given to seventh (VII) grade students of SMP 4 Pamekasan which were 26 students. The results of observations, tests, and interviews were student's conceptual understanding in visualization phase is good, this could be seen from the results of observations when learning took place as follows:

a.

Table 7 The Analysis Result of Observation in $2^{\text {nd }}$ Meeting

\begin{tabular}{|c|c|c|c|c|}
\hline \multirow{3}{*}{ Assessed Aspects } & \multirow{2}{*}{\multicolumn{2}{|c|}{$\frac{\text { Percentage }(\%)}{\text { Observer }}$}} & \multirow{3}{*}{ Average } & \multirow{3}{*}{ Category } \\
\hline & & & & \\
\hline & (1) & (2) & & \\
\hline $\begin{array}{l}\text { Information Stage } \\
\text { - Finding information }\end{array}$ & $100 \%$ & $100 \%$ & $100 \%$ & Very good \\
\hline $\begin{array}{l}\text { Guide orientation Stage } \\
-\quad \text { Re-stating a concept }\end{array}$ & $100 \%$ & $100 \%$ & $100 \%$ & Very good \\
\hline $\begin{array}{l}\text { Explication Stage } \\
\text { - Clarifying an object based on a certain characteristic } \\
\text { - Giving examples and not examples of concepts }\end{array}$ & $87,5 \%$ & $87,5 \%$ & $87,5 \%$ & Very good \\
\hline $\begin{array}{l}\text { Free Orientation Stage } \\
\text { - Presenting concepts in the form of representation } \\
\text { - Developing sufficient requirements and necessary } \\
\text { requirements. } \\
\text { - Using, utilizing and choosing procedures or } \\
\text { operations }\end{array}$ & $87,5 \%$ & $88 \%$ & $87,8 \%$ & Very good \\
\hline $\begin{array}{l}\text { Integration Stage } \\
\text { - Students are able to apply concepts or algorithms to } \\
\text { solve mathematical concepts }\end{array}$ & $91,6 \%$ & $91,6 \%$ & $91,6 \%$ & Very good \\
\hline
\end{tabular}

Based on the results of these observations, it could be stated that the level of student's conceptual understanding had been very good. Student's conceptual understanding was measured from the steps of Van Hiele's learning theory which involved indicators of conceptual understanding in the learning process. Conceptual understanding in this study was not only seen based on observation, but also involved the results of tests and interview, the following are the results of written tests on 26 students in the visualization phase:

b. Table 8 The Analysis Result of Test

\begin{tabular}{llcc}
\hline No & \multicolumn{1}{c}{ Indicators } & Average (\%) & Category \\
\hline 1. & Re-stating a concept & 80.26 & Very good \\
2. & Clarifying object based on certain character according to the concept & 81.63 & Very good \\
3. & Giving an example and not example of the concept & 79.63 & Good \\
4. & Presenting concepts in various forms of mathematical representation & 82.74 & Very good \\
5. & Developing necessary requirements and sufficient requirements in a & 78.78 & Good \\
6. & Concept & 71.96 & Good \\
7. & Applying and selecting certain procedures or operations & 71.78 & Good \\
\hline & Total & $\mathbf{7 8 . 1 1}$ & Good \\
\hline
\end{tabular}

The test results of 26 students in the visualization phase could be stated that student's conceptual understanding is good with the average was $78.11 \%$. Student's conceptual understanding was assessed through tests which carried out when the learning process had done. The material that had been discussed was quadrilateral and triangle. Test results showed that students had the good level of conceptual understanding. On indicators 1,2 and 4 the student's conceptual understanding had been very good. The other indicators were good. The student's conceptual understanding was good because more than $70 \%$ of students had been able to answer the seven indicators. 
The analysis results of conceptual understanding were based on a test consisted of 7 questions analyzed by using achievement indicators of conceptual understanding. However, to prove the results of the test whether the students worked individually or in groups, the researchers took 5 students randomly to be interviewed.

Based on the results of the interview, it can be seen the level of student's conceptual understanding about the quadrilateral and triangle shapes. In the interview, some students could distinguish the characteristics of each plane. Thus, it can be stated that by using Van Hiele's learning theory and the spinning wheel media, students in the visualization phase can understand the concept. It was supported by evidence which was the test results used questions from Van Hiele. The students average scores were $>70$, which meant that the students were already in the second phase, namely the analysis phase where students not only recognized the name of the plane, but students already knew the definition and characters of the plane. It could also be said that the student's understanding skills were very good.

Table 9 The Result of Pre-test dan Post-test by Using Spinning Wheel Media

\begin{tabular}{clcc}
\hline No & The result of the test & Average Score & Phase Category \\
\hline $\mathbf{1}$ & Before & 2,88 & Visualization \\
$\mathbf{2}$ & After & 7,44 & Analysis \\
\hline
\end{tabular}

Based on the results of the Pre-test and Post-test, it could be concluded that the spinning wheel media used in the learning process towards the visualization phase combined with Van Hiele's learning theory was effective. When students were tested before using the spinning wheel media and learning process, students were still in the category of visualization thinking level, but after the learning process took place the results showed that the student's average score was already in the second category of Van Hiele's thinking level, which was analysis level / phase.

\section{Discussion}

Based on the results of research conducted at SMPN 4 Pamekasan about student's conceptual understanding who were at in visualization phase level of thinking, using the spinning wheel as learning media and applying Van Hiele's learning theory could be said as successful. This was proofed by the final results of students who had succeeded in increasing their understanding of concepts and increasing their level of thinking, from the visualization phase to the analysis phase. The spinning wheel media designed based on the student's level of thinking. It could attract a student's interest in learning and curious about the plane (triangles and rectangles), so the learning process can be understood perfectly. This also could be proven from the results of observations, which was $89.50 \%$ of students had been able to understand the concept. They could achieve the "very good" category in understanding the concept plane. In addition, the results of tests conducted on 26 students who had a good category of conceptual understanding with average were $78.11 \%$. It also supported by the interview conducted after the tests. The last was the Van Hiele test which was implemented to prove the effectiveness of the spinning wheel media.

Based on the final test results, it could be stated that the media designed was effective and feasible to be used, it was because students who were initially in visualization phase, after going through the learning process and the application of media, could increase to the analysis phase. $74.4 \%$ of them were in the analysis phase. 
This research finding was in line with the research conducted by Halim (2015) which stated that learning media could help students in the learning process, why? Because learning media could attract the student's learning interest, so students could enjoy the learning process. It also supported by Mariani (2016), in the results of his research he said that media could easily stimulate the brain's performance of students, so everything that teacher said will enter perfectly into student's brains, student's understanding of a basic concept could easily get into student's minds by using learning media.

\section{CONCLUSION}

The implementation of Van Hiele's learning theory and spinning could make students in the visualization phase know about plane, elements, and types. Students also knew and understood about plane and its parts. This can be seen from the student's observation and discussion results held when learning took place.

Most of the seventh (VII) grade students of SMPN 4 Pamekasan had fulfilled indicators of conceptual understanding. This was known from the results of tests and interview given by the researcher, which each indicator had a different average. In test analysis, it could be seen that $100 \%$ of students were able to answer Van Hiele test questions in the visualization phase very well, and $90 \%$ of students were able to answer the Van Hiele test questions in the analysis phase. Students could be stated that they increase their level of thinking to the analysis phase. This proved that the student's conceptual understanding was good. It also supported also by the results of interview tests for several students to support student's answers on the test.

The level of student's conceptual understanding of in junior high school 4Pamekasanwas classified into two categories, namely very good and good. Therefore, the spinning wheel media could be said as effective in this learning process. It could be proven by the results of previous tests that students in the visualization phase did not know about the plane. After used the spinning wheel media and applied the Van Hiele's learning theory, the test results stated that students go up to the second phase which was analysis phase. In this phase students already knew, recognized, and understood the type of plane along with its parts or traits. Thus, the spinning wheel media could be stated as effective media to be used in learning plane geometry..

\section{REFERENCES}

Al-ebous, T. (2016). Effect of the Van Hiele Model in Geometric Concepts Acquisition: The Attitudes towards Geometry and Learning Transfer Effect of the First Three Grades Students in Jordan, 9(4), 87-98.

Alex, J. K., \& Mammen, J. K. (2015), Lessons Learnt from Employing van Hiele Theory Based Instruction in Senior Secondary School Geometry Classrooms. Eurasia Journal of Mathematics, Science \& Technology Education, 2016, 12(8), 2223-2236 doi: 10.12973/eurasia.2016.1228a

Alqahtani, M.M. \& Powell, A.B. (2016). Instrumental Appropriation of a Collaborative,Dynamic-Geometry Environment and Geometrical Understanding. InternationalJournal of Education in Mathematics, Science and Technology, 4(2), 72-83

Arikunto, suharsimi. (2013). Prosedur Penelitian Suatu Pendekatan Praktik. Jakarta: PT. Rineka Cipta 
Armah, R.B., Cofie, P.O., \& Okpoti, C.A. (2018). Investigating the effect of van Hiele Phasebased instruction on pre-service teachers' geometric thinking. International Journal of Research in Education and Science (IJRES), 4(1), 314-330. DOI:10.21890/ijres.383201

Asrul, Karim. (2011). Penerapan Metode Penemuan terbimbing dalam Pembelajaran Matematika untuk meningkatkan Pemahaman Konsep dan Kemampuan Berfikir Siswa Sekolah Dasar. Jurnal Pendidikan Universitas Negeri Surabaya, Vol.2 No.1, Hal 20-39

Gravemeijer, K \& Cobb, P. (2006). Design Research From A Learning Design Perspective. EducationalDesign Research.

Gravemeijer, K \& Cobb, P. (2008). Experimenting to Support and Understand Learning Processes. Handbook of Design Research Methods in Education.

Halim, Abdulllah. (2015). The Effects of Van Hiele's Phases of Learning Geometry on Student's Degree of Acquisition of Van Hiele Levels. International Journal Procedia - Social and Behavioral Sciences Volume 102, Pages 251-266

Ketut, Sutama. (2014). Pengembangan Perangkat Pembelajaran Geometri Berdasarkan Teori Van Hiele Berbantuan Wingeom Dalam Upaya Meningkatkan Aktivitas Dan Hasil Belajar Siswa. e-Journal Program Pascasarjana Universitas Pendidikan Ganesha Program Studi Matematika, Vol.6 No.2, Hal 11-21

Mariani, Andi. (2016). The Effect Of Van Hiele Learning Model Toward Geometric Reasoning Ability Based On Self-Efficacy Of Senior High School Students. Internation Journal of Mathematics Education, Vol 1 No 2

Safrina, Khusnul. (2014). Peningkatan Kemampuan Pemecahan Masalah Geometri Melalui Pembellajaran Kooperatif Berbasis Teori Van Hiele. Jurnal Didaktik Matematika, Vol.5 No.1, Hal 57-69

Salim, K. \&Tiawa D.H. (2015). Implementation of Structured Inquiry Based Model Learning Toward Student's Understanding of Geometry. International Journal of Research in Education and Science (IJRES), 1(1), 75-83.

Susanti, wiwi. (2011). Efektivitas model pembelajaran Van Hiele dengan alat peraga untuk meningkatkan hasil belajar siswa pada materi pokok bangun ruang sisi datar. Jurnal Pendidikan Matematika IAIN, Vol.1 No.4, Hal 24-41

Susilana, rudi. (2009)."MEDIA PEMBELAJARAN". Bandung: CV Wacana prima

Usiskin, Z. (1982). Van Hiele Levels and Achievement in Secondary School Geometry. (Final report of the Cognitive Development and Achievement in Secondary School Geometry Project.) Chicago: University of Chicago. (ERIC Document Reproduction Service No. ED220288)

Yadil, Nur. (2009). Penerapan Model Pembelajaran van hiele untuk meningkatkan pemahaman siswa SMP karunadipa palu terhadap konsep bangun-bangun segiempat. Journal Matematika FMIPA UNY, Vol.1 No.4, Hal 19-27

Yeni, Ety. M. (2011). Pemanfaatan benda-benda manipulatif untuk meningkatkan pemahaman konsep geometri dengan kemampuan tilikan ruang siswa kelas $\mathrm{V}$ sekolah dasar. Jurnal Pendidikan Matematika Provinsi Aceh, Vol.2 No.4, Hal 26-43 